\title{
ARTIKKELIT
}

\section{Kotona asuvan muistisairaan henkilön ja hänen läheistensä teknologiaan liittyvät tarpeet ja toiveet}

\author{
${\text { Merja Riikonen }{ }^{1} \text { ja Eija Paavilainen }}^{2}$ \\ ${ }^{1}$ Jyväskylän yliopisto, terveystieteiden laitos \\ ${ }^{2}$ Tampereen yliopisto, boitotieteen laitos
}

\begin{abstract}
Tutkimuksessa selvitettiin millaisia tarpeita ja toiveita kotona asuvilla muistisairailla ja heidän läheisillään on kotona asumista tukevaan teknologiaan liittyen. Tutkimukseen osallistui 25 kotona asuvaa muistisairasta henkilöä ja 25 heidän läheistään. Metodina käytettiin etnografista tutkimusotetta. Aineistonkeruumenetelminä olivat avoin haastattelua ja havainnointi. Analyysimenetelmänä käytettiin sisällön analyysiä. Tarpeet ja toiveet voitiin luokitella kolmeen pääluokkaan, jotka olivat itsemääräämisoikeuden säilyminen, sosiaalisten suhteiden säilyminen ja liikkumisen oikeus ja turvallisuus. Haasteita olivat yksinäisyyden kokemus, muistin ja toimintakyvyn heikkenemiseen liittyvät ongelmat ja rajoitettu liikkuminen. Muistisairas ihminen koki lukitut ovet itsemääräämisoikeutensa rajoittamisena. Muistin heikkenemisen hän koki hämmentävänä ja toivoi siihen apua teknologiasta. Läheisen kokemus liittyi muistin heikkenemisen konkreettisiin seurauksiin päivittäisissä toiminnoissa ja kommunikoinnissa. He kaipasivat erityisesti näiden haasteiden ratkaisemiseen teknologialta apua. Huoli fyysisestä turvattomuudesta oli läheisillä suurempi, kun taas muistisairaat ihmiset kokivat enemmän psykososiaalista turvattomuutta.
\end{abstract}

\section{Johdanto}

Yhteiskunnassamme etsitään keinoja muistisairaiden ihmisten hyvinvoinnin ja arvokkaan arjen mahdollistamiseen etenevästä sairaudesta huolimatta. Alzheimer's Disease International (2015) raportoi muistisairaiden ihmisten määrän kasvaneen viimeisten vuosien aikana. Maailmanlaajuisesti muistisairauteen sairastuneita ihmisiä oli vuonna 2015 noin 46,78 miljoonaa. Luvun odotetaan nousevan 74,69 miljoonaan vuoteen 2030 mennessä ja 131,45 miljoonaan vuoteen 2050 mennessä (World Alzheimer Report 2015). Viramon ja Sulkavan (2015) arvion mukaan Suomessa on 93000 keskivaikeasti ja vaikeasti muistisairasta henkilöä. Lievää kognitiivista heikentymistä arvioidaan sairastavan noin 200000 ja Lievää muistisairautta 100000 suomalaista. Etenevään muistisairauteen arvioidaan vuosittain sairastuvan 
14500 yli 64-vuotiasta suomalaista (Viramo \& Sulkava 2015; Käypähoito suositus 2017).

Viime aikoina on tuotu esiin muistisairaan ihmisen oikeutta arvokkaaseen ja turvalliseen elämään (mm. Holstein, Parks \& Waymack 2010, Kansallinen muistiohjelma 2012). Muistisairaan ihmisen tulee saada toteuttaa arvojaan, tapojaan ja rutiinejaan mahdollisimman pitkään (Holstein, Parks \& Waymack 2010; Kansallinen muistiohjelma 2012). Nykyinen suuntaus kotihoidon lisäämiseksi ja laitoshoidon vähentämiseksi haastaa selvittämään sitä, miten muistisairaat ihmiset voisivat elää omassa kodissaan mahdollisimman pitkään itsenäisesti. Toisaalta on pohdittava, miten pitkään se on inhimillisesti oikea ratkaisu (esim. Jyrkämä 2015).

Yhteiskuntamme peruslinjauksia ikääntyneiden hoidossa on kotona asumisen tukeminen. Suomessa Vanhuspalvelulaki ja hallituksen rakennepoliittinen ohjelma vuosille 20132015 painottavat laitoshoidon vähentämistä ja kotona annettavan tuen lisäämistä (Laki ikääntyneen väestön toimintakyvyn tukemisesta sekä iäkkäiden sosiaali- ja terveyspalveluista 2012). Tähän pyrkiessämme meillä tulisi olla erityisesti tietoa kotona asuvien muistisairaiden ihmisten tarpeista. Teknologiaa on kehitetty ikääntyneiden käyttöön jo useita vuosikymmeniä. Se on kuitenkin juurtunut hitaasti laajemmin osaksi ikääntyneiden arkea (Taipale 2014; Topo 2015). Edelleen kaivataan tutkimusta siitä, miten teknologia aidosti vastaisi ikääntyneiden ja erityisesti muistisairaiden ihmisten arjen tarpeisiin (van der Roest, Wenborn, Pastink, Droes \& Orrell 2017; Meiland ym. 2017; Topo 2009). Melko harvat yritykset ovat keskittyneet kehittämään laadukkaita muistiystävällisiä teknologiaratkaisuja (Ympäristöministeriön raportti 7/2017).

Marshall (2009) on kuvannut länsimaista yhteiskuntaa riskejä kaihtavaksi yhteiskunnaksi, joka vammauttaa muistisairasta ihmistä yhä enemmän kieltämällä heiltä normaalin arjen ja siihen liittyvän riskien oton. Asioita, joita he ovat aikaisemmin tottuneet tekemään, kielletään turvallisuuden nimissä. Tällöin muistisairaan ihmisen itsemääräämisoikeutta rajoitetaan ja itseluottamusta heikennetään. Teknologia voi olla yksi ratkaisu mahdollistaessaan muistisairaille ihmisille itsenäisemmän ja turvallisemman arjen (Marshall 2009). Teknologialla tässä tutkimuksessa tarkoitetaan kotona asumista tukevia, menetettyjä taitoja kompensoivia sekä turvallisuutta ja omatoimisuutta lisääviä laitteita ja niihin liittyviä palveluja. Artikkelissa etsitään vastauksia kysymykseen, mitkä ovat muistisairaiden ihmisten ja heidän läheistensä teknologiaan liittyvät tarpeet ja toiveet ja erityisesti se miten teknologia voi toimia arjen apuna.

\section{Teknologia muistisairaan arjessa}

Leikaksen (2008) mukaan teknologian elämälähtöinen suunnittelu (Life-Based Design) lähtee ajatuksesta, että teknologian suunnittelussa lähdetään alusta asti käyttäjien tarpeista, ei teknologisesta näkökulmasta. Tässä käyttäjälähtöisyyttä (Human-Based Desing) holistisemmassa näkökulmassa ajatellaan, että suunnittelu tulee aloittaa käyttäjien elämänmuodon tarkastelulla. Tällöin kartoitetaan ihmisen toiminnan lisäksi elämänmuotoon vaikuttavat fyysiset, psyykkiset ja sosiokulttuuriset tekijät sekä ihmisen arvot, tarpeet, toiveet ja odotukset. Näin varmistetaan se, että kehitetään nimenomaan käyttäjien elämän kannalta tarpeellisia tuotteita ja vältetään teknologiakeskeisyys (Leikas 2008). Pelkkä teknologian käytettävyys ei riitä, jos teknologinen apuväline ei tue käyttäjän arkea, ole hänen arvojensa mukainen tai täytä hänen tarpeitaan (Leikas \& Saariluoma 2008).

Vanhus- ja lähimmäispalvelun liiton (2017) raportin mukaan tällä hetkellä Suomessa markkinoilla on saatavissa monenlaisia kotona asumista tukevia teknisiä laitteita. Ikäteknologian kategoriaan kuuluu paljon sellaisia laitteita, jotka vaativat käyttäjältään kognitiivisia kykyjä, kuten erilaiset hätäpainikkeet. Erityisesti 
muistisairaiden ihmisten käyttöön sopivia ovat mm. ovihälyttimet, palohälyttimet, kaatumishälyttimet, erilaiset paikantimet sisä- ja ulkotiloihin ja niihin liittyvä aluevalvonta. Markkinoilla on myös vuoteestapoistumis- ja lattiahälyttimiä, aktiivisuusrannekkeita, vesivuodon tunnistimia, helppokäyttöisiä puhelimia, erilaisia liesivahteja, vuorokausikalentereita ja lääkemuistuttajia. Lisäksi on olemassa erilaisia kuntouttavia ja viihdyttäviä sovelluksia, kuten internetpohjaiset musiikki- ja muistelusovellukset ja kuvapuhelinyhteyden mahdollistavat laitteet (Forsberg \& Stenberg 2017; myös Ympäristoministeriön raportti 7/2017).

Kansainvälisessä tutkimuksissa on tuloksia siitä, että teknologian käyttö muistisairaan tukena lisäsi vapautta liikkua lähiympäristössä turvallisesti (Margot-Catting \& Nygård 2006; Faucounau, Wu, Boulay, Maestrutti \& Rigaud 2009; Pot, Willemse \& Horjus 2012; Olsson, Engström, Lampic \& Skovdahl 2013; Petonito, Muschert, Carr, Kinney, Robbins \& Brown 2013; Meiland ym. 2016), muistutti ja rauhoitti arjen tilanteissa (Altus, Mathews, Xaverius, Engelman \& Nolan 2000; Meiland ym. 2012), tuki vuorokausirytmiä ja ajan orientaatiota (Nygård \& Johansson 2001; Topo 2007; Meiland ym. 2014) sekä vähensi ahdistuneisuutta (Baruch, Downs, Baldwin \& Bruce 2004).

Muistisairaan ihmisen ja läheisen tarpeet teknologiaan liittyen

Eloniemi-Sulkavan \& Savikon (2011) mukaan muistisairaan ihmisen arjen elämään vaikuttavat muistisairauteen liittyvät erilaiset kognitiiviset oireet. Niitä ovat $\mathrm{mm}$. vaikeus suorittaa useita peräkkäisiä tehtäviä ja vaikeus oppia uutta. Sairauteen liittyy myös paikan ja ajan orientaation heikentymistä, joka lisää levottomuutta ja voi aiheuttaa myös eksymistä. Toiminnanohjauksen ongelmat heikentävät aloitettujen tehtävien muistamista ja niiden loppuun viemistä (Eloniemi-Sulkava \&Savikko 2011). Kognitiiviset muutokset altistavat tunne- ja käyttäytymismuutoksiin kuten ahdistuneisuuteen ja levottomuuteen (Whall \& Kolanowski 2004).

Muistisairaiden ihmisten tarpeita ja toiveita teknologisten apuvälineiden suhteen ei ole paljokaan tutkittu. Toki osittain samat tarpeet kuin muistisairailla yleensä ovat tärkeitä myös teknologiaa valittaessa. Kutzleben ja kumppanit (2012) ovat kirjallisuuskatsauksessaan todenneet, että kotiympäristössä asuvien muistisairaiden ihmisten teknologiaan liittyviä toiveita ja tarpeita teknologiaan liittyen, on tutkittu niukasti (Kutzleben ym. 2012; myös Thielke ym. 2012). Katsauksessa korostettiin tarpeiden perustuvan yleisinhimillisiin tarpeisiin. Näitä oli eri tutkimuksista esim. tarve kontrollin säilyttämiseen (de Boer ym. 2007; Steeman ym. 2007; van der Roest ym. 2007), aikaisemman elämäntavan säilyttämiseen (Ablitt ym. 2009; van der Roest ym. 2007), sosiaalisen ympäristön turvallisuuteen ja ymmärretyksi tulemiseen (de Boer ym. 2007; Ablit ym. 2009) sekä kompensaatiokeinojen löytämiseen (Ablit ym. 2009; Steeman ym. 2007; van der Roest 2007).

Muistisairaan ihmisen ja heidän omaistensa tarpeita yleisellä tasolla tutkinut MirandaCastillo kumppaneineen (2010) on löytänyt 152 kotona asuvaa muistisairasta ihmistä ja 128 omaishoitajaa haastateltuaan, tärkeimmiksi tarpeiksi mielekkään toiminnan, sosiaalisen toiminnan ja psykologisen ahdistuksen lievittäminen (Miranda-Castillo ym. 2010). Muistisairaiden ihmisten omassa kokemuksessa nousee tärkeimmäksi psykologisen ahdistuksen lievittämisen tarve (Miranda-Castillo, Woods \& Orrell 2013).

Marshallin (2009) mukaan muistisairaan ihmisen tarpeet ovat hyvin samanlaisia kuin kognitiivisesti terveiden, mutta heidän kykynsä tiedostaa tarpeensa ja täyttää ne itsenäisesti ovat heikentyneet. Teknologia voi olla osaltaan auttamassa muistisairasta kohtaamaan tarpeensa ja täyttämään niitä (Marshall 2009). Kuten kognitiivisesti terveillä, myös muistisairailla ihmisillä tarpeet ovat yksilöllisiä, sillä jokainen on hieman eri vaiheessa sairautta, elää 
erilaisessa ympäristössä ja on persoonaltaan erilainen (Lawton 1982; Marshall 2009).

Omaishoitajan ja muistisairaan ihmisen käsityksissä tarpeista on eroja. Omaishoitajat ja läheiset kiinnittävät huomiota pääasiassa hoitoon, fyysiseen toimintakykyyn ja turvallisuuteen liittyviin tarpeisiin (Harris 2006) sekä sosiaalisen vetäytymiseen, jolloin muistisairas henkilö alkaa vetäytyä harrastuksista ja hänelle aiemmin ominaisesta sosiaalisesta kanssakäymisestä (Bank ym. 2006). Lisäksi ulkona liikkumiseen liittyvä rajoittaminen nousee esiin (Bank, Arguelles, Rubert, Eisdorfer \& Czaja 2006). Cohen-Mansfieldin ja kumppanien mukaan muistisairaat ihmiset itse kokevat ongelmaksi mielekkään tekemisen puutteen ja pitkästymisen sekä yksinäisyyden (CohenMansfield, Dakheel-Ali, Marx, Thein \& Regier 2015). Harris (2006) löysi näiden lisäksi ongelmat nukkumisessa sekä turvattomuuden kokemukset tilanteissa, joissa he eivät tiedä missä he ovat ja mikä päivä on. Teknologiaa on kehitetty pääasiassa palvelujärjestelmän ja omaishoitajien tarpeisiin ja muistisairaan ihmisen tarpeet ovat jääneet vielä vähemmälle huomiolle (Topo 2009; van der Roest, Wenborn, Pastink, Droes \& Orrell 2017).

\section{Tutkimuksen toteutus}

Tässä artikkelissa esitetyt tulokset ovat osa interventiotutkimusta, jossa kartoitettiin muistisairaan ihmisen tarpeita ja valittiin markkinoilla olevista laitteista yksilöllisesti kullekin sopivat teknologiat sekä rakennettiin yksilöllinen turvaverkko. Teknisiä sovelluksia muistisairaat ihmiset käyttivät aidoissa kotioloissa 14 kuukauden ajan, jonka jälkeen tehtiin arviointi ja seuranta. Tämä artikkeli keskittyyy kartoitusvaiheen tuloksiin.

Interventiotutkimuksen aineistonkeruu toteutettiin Eeva - yksilöllinen turvaverkko dementoituville -hankkeessa vuosina 2004-2006 ja siihen liittyvässä seurannassa vuonna 2007. Hanke toteutettiin Etelä-Pohjanmaan alueel- la. Päärahoittajana toimi Etelä-Pohjanmaan maaseutuohjelma ALMA. Hankkeen toteutti Etelä-Pohjanmaan terveysteknologian kehittämiskeskus yhteistyössä Seinäjoen keskussairaalan, pilottikuntien (Ilmajoki, Seinäjoki, Alajärvi, Alavus, Lapua ja Jurva) sekä Etelä-Pohjanmaan Muistiyhdistyksen kanssa. Aineisto on keräämisajankohdastaan huolimatta edelleen ajankohtainen, sillä muistisairaiden ihmisten ja läheisten tarpeet ja toiveet teknologian tuesta kodin arjessa eivät ole tänä aikana paljonkaan muuttuneet.

Eeva-hankkeen tavoitteena oli rakentaa kotona asuville muistisairaille henkilöille yksilöllisesti räätälöity turvaverkko teknologian tukemana omaisista, sukulaisista, ystävistä, naapureista, kyläläisistä, kuntien kotipalvelusta, palveluyrityksistä, järjestöistä, diakoniatyöstä ja vapaaehtoisista. Turvaverkolla tarkoitetaan tässä sitä kokonaisuutta, joka muodostui muistisairaan ihmisen arjessa läheisistä, ystävistä, naapureista, hoiva- ja hoitopalvelujen ja teknisten välineiden kokonaisuudesta.

\section{Osallistujat ja käytetty teknologia}

Kaikki tutkimukseen osallistuneet olivat mukana myös osatutkimuksessa, josta tässä artikkelissa raportoidaan. Tutkimukseen osallistui 25 muistisairasta kotona yksin tai omaishoitajansa kanssa asuvaa henkilöä sekä 25 heidän läheistään. Osallistumisen kriteereinä oli diagnosoitu Alzheimerin tauti, vaskulaarinen muistisairaus tai näiden sekamuoto. Osallistujat olivat kuudesta kunnasta Etelä-Pohjanmaan alueelta ja heillä oli kaikilla Seinäjoen keskussairaalassa diagnosoitu muistisairaus. Osallistujien valintaan vaikuttivat laajemman hankkeen tavoitteiden mukaisesti muistisairaan lisääntynyt avuntarve. Ikä tai muistisairauden aste eivät vaikuttaneet valintaan. Läheisen osalta ei ollut valintakriteerejä.

Eeva-hankkeessa tutkimukseen osallistuneista 18 asui pienissä maalaisyhteisöissä ja seitsemän pienissä kuntataajamissa. Asumismuoto oli pääasiallisesti omakotitalo: 21 asui 
omakotitalossa, kolme rivitalossa ja yksi kerrostalossa. Tutkimukseen osallistuneista muistisairaista ihmisistä viisi oli miehiä ja 20 naisia. Intervention alussa lievässä vaiheessa oli 12 osallistujaa, keskivaikeassa vaiheessa sairautta kymmenen ja vaikeassa vaiheessa kolme osallistujaa. Näiden kolmen vaikean vaiheen osallistujan kohdalla informanttina toimiminen rajoittui sen hetkisen tunnetilan ja kokemuksen ilmaisuun ja tutkijan havainnointiin. Tutkimukseen osallistuneista muistisairaan läheisistä poikia oli kahdeksan, tyttäriä 11, vaimoja kaksi, aviomiehiä yksi, veljiä kaksi, vävyjä yksi ja sisarentyttäriä yksi. Tutkimuksessa mukana olleista läheisistä 21 henkilöä oli alle 65-vuotiaita ja neljä oli yli 65-vuotiaita.

Yhdellä henkilöllä oli Alzheimerin taudin ja vaskulaarisen muistisairauden sekamuoto ja hänen sairautensa oli keskivaikeassa vaiheessa. Kaksi 25:stä osallistujasta keskeytti tutkimuksen: yksi siirtyy laitoshoitoon ja yksi kuoli heti tutkimusvaiheen alussa. Ikäjakauma oli 54-90 vuotta ja keskimääräinen ikä 79 vuotta.

Interventiotutkimuksen alkukartoitukseen liittyvässä tarvekartoituksessa osallistujilla oli hyvin vähän aikaisempaa tietoa kotona asumista tukevista teknologisista ratkaisuista. Tarvekartoituksen aikana osallistujien esittäessä tarpeitaan ja toiveitaan tapaamisessa mukana ollut teknologia-asiantuntija kertoi teknologioista, joista voisi olla juuri tähän esiin tuotuun tarpeen täyttämiseen apua. Esimerkiksi kun muistisairas ihminen kertoo, miten lääkkeet unohtuvat ottaa aikanaan, hänelle kerrottiin lääkekellosta,joka muistuttaa ja antaa aina oikean lääkkeen. Sen jälkeen keskusteltiin yhdessä muistisairaan ihmisen ja hänen läheisensä kanssa olisiko tällainen teknologinen apuväline sopiva juuri heidän käyttöönsä.

Teknologiavalikoima, joista tarvekartoituksen aikana tarjottiin sovelluksia käyttöön räätölöidysti jokaiselle henkilölle erikseen, oli 29 erilaista markkinoilla ollutta ratkaisua. Tärkeimpiä näistä olivat vuodeturva, lattiaturva, lääkekello, kaatumisvahti, liesiturva, viivästetty oviturva, helppokäyttöinen puhelin, palovaroi- tin, josta hälytys lähti eteenpäin, GSM-kamera, liiketunnistinvalot, turvapuhelin, henkilöpaikantimet, aluevalvontalaitteet, GPS-kello, liukastumista estävät apuvälineet, kuulonvahvistimet ja erilaiset kahvat.

Viimeisimpien Suomessa tehtyjen raporttien mukaan kaikki Eeva-hankkeessa käytetyt laitteet ovat edelleen tärkeä osa tämän hetken teknologisia apuvälineitä. Sovellukset ovat toki kehittyneet, integroituneet isommiksi kokonaisuuksiksi ja monipuolistuneet, mutta toimintaperiaatteet ja -tarkoitukset ovat pysyneet melko samankaltaisina (Ympäristöministeriön raportti 7/2017, Forsberg \& Stenberg 2017).

\section{Menetelmät}

Tutkimusaineisto kerättiin etnografisen menetelmän keinoin ja aineistonkeruumenetelminä käytettiin avoimia haastatteluja, osallistuvaa havainnointia sekä kenttäpäiväkirjaa (Fetterman 2010). Haastattelutilanteet lähenivät monissa tilanteissa enemmän vapaata keskustelua kuin haastattelua. Haastatteluaineisto analysoitiin sisällönanalyysin avulla. Oleellisena osana tutkimuksen toteusta oli kenttätyö ja monien eri lähteiden käyttö ja sitä kautta aineiston monipuolisuus (ks. Eskola \& Suoranta 1998). Pyrkimyksenä oli päästä sisälle tutkittavien maailmaan. Etnografiassa kentän käsitettä käytetään varsin joustavasti ja onkin esitetty, että kenttä tulisi ymmärtää enemmän sosiaalisista suhteista muodostuvaksi tilaksi kuin fyysiseksi paikaksi (Helkama, Myllyniemi \& Liebkind 2005). Kentäksi ymmärrettiin kodin ja sen lähiympäristön muodostama fyysinen, psyykkinen ja sosiaalinen ympäristö.

Etnografiseen tutkimusotteeseen kuuluvalla osallistuvan havainnoinnin avulla (ks. Hirvonen \& Nikkonen ym. 2003) tutkija osallistuu tutkimukseen osallistuvien toimintaan. Tutkijan rooli ei siis ole olla ulkopuolinen tarkkailija vaan tulla mahdollisimman lähelle tutkimukseen osallistuvia (Hammersley \& Atkinson 1996, Nisula 1998). Tutkimuksessa pyrittiin luomaan luottamuksellinen suhde 
osallistujan ja tutkijan välille mahdollisimman todenmukaisen kuvan saamiseksi osallistujien tarpeista ja toiveista.

Hirvosen \& Nikkosen (2003) mukaan osallistujien oman kokemuksen nostaminen esiin erityisesti erilaisissa elämän käännekohdissa liittyy etnografiseen näkökulmaan. Tällöin ollaan kiinnostuneita siitä, millaisia merkityksiä osallistujat antavat omille kokemuksilleen (Hirvonen \& Nikkonen 2003). Tutkimuksen osallistuneet muistisairaat ihmiset ja heidän lähipiirinsä ovat kokeneet suuren elämänmuutoksen. He siirtyvät sairauden edetessä jatkuvasti uusiin rooleihin niin sairastuneina kuin läheisinäkin.

\section{Aineisto}

Tässä artikkelissa käytettyä aineistoa kerättäessa tutkija oli mukana tarvekartoituksessa havainnoijana ja toimijana. Osallistujien kanssa tehtiin yksilöllinen ja kokonaisvaltainen kartoitus, jossa etsittiin muistisairaan ja läheisen kokemuksia arjen tarpeista ja haasteista. Artikkelin aineistona on käytetty tarvekartoitukseen materiaalista. Haastattelutilanteet olivat hyvin vapaamuotoisia ja käynnillä jokaisen muistisairaan kodissa oltiin keskimäärin 3 tuntia. Tilanteissa pyrittiin mahdollisimman luonnolliseen kommunikointiin.

Haastattelun aikana käytiin läpi seuraavat kysymykset: 1 . Sosiaaliset tekijät: millainen on lähipiirin merkitys, mitä harrastaa ja mikä sosiaalisten kontaktien merkitys. 2. Toimintakyky ja fyysiset tekijät: mitä kykenee tekemään itse ja mihin tarvitsee apua, miten muistisairauden oireet vaikuttavat arkeen, onko muita sairauksia sekä kuinka paljon liikkuu. 3. Psyykkiset tekijät: mistä asioista pitää ja pelkääkö jotain arjessa, millaiseksi osallistuja kokee mielialansa, onko vaaratilanteita, kokeeko olonsa turvalliseksi vai turvattomaksi ja onko eksymisen kokemuksia. 4. Teknologiset apuvälineet: onko apuvälineitä ja miten suhtautuu niiden käyttöön.
Tutkimuksessa havainnointimuistiinpanot täydensivät haastatteluja. Havainnointia ohjasi havainnointirunko, jossa havainnoinnin kohteita olivat ilmeet, eleet, kehonkieli ja kontaktit ympäristöön. Havainnoinnissa on kiinnitetty myös huomiota muistisairaan henkilön tunnetilaan ja puheen sävyyn, omaishoitajan ja muistisairaan henkilön väliseen kommunikaatioon sekä fyysiseen tilaan ja sen turvallisuuteen. Haastattelutilanteessa kirjatut havainnot kirjoitettiin tarkemmiksi havainnointimuistiinpanoiksi heti haastattelutilanteen jälkeen. Kaikki keskustelut nauhoitettiin ja ne sekä havainnointimuistiinpanot litteroitiin valikoiden laajasta strukturoimattomasta haastattelumateriaalista. Havainnointimuistiinpanot kirjoitettiin myös puhtaaksi. Kenttäpäiväkirjan merkintöjen avulla reflektoitiin tutkijan omaa ajattelua ja roolia tutkimustilanteista.

Muistisairaan henkilön lisäksi tarvekartoitustilanteessa oli mukana joku muistisairaan läheiseksi kokema henkilö, joka myös osallistui tutkimukseen. Muistisairaalla ihmisellä on usein vaikeuksia ilmaista itseään, joten myös omaisen on hyvä olla mukana keskustelussa (Mäki \& Topo 2009). Myös sosiaalisen kontekstin ja arjen vuorovaikutuksen kannalta oli tärkeää seurata läheisten ja muistisairaiden henkilöiden keskustelua ja niistä esiin nousevia piirteitä. Läheiset kertoivat myös oman näkökulmansa arjen tarpeista ja teknologiaan liittyvistä toiveista.

Muistisairaan oman mielipiteen kuuluminen pyrittiin varmistamaan kysymällä haastattelutilanteessa uudelleen muistisairaalta henkilöltä kysymys, jos omainen oli vastannut kysymykseen muistisairaan puolesta. Tarvittaessa muistisairaan ihmisen kanssa keskusteltiin kahdestaan ilman omaista jossakin rauhallisessa tilassa. Näissä tilanteissa havainnoinnin merkitys korostui muistisairaan ihmisen aidon kokemuksen ja mielipiteen kuulemisessa. 


\section{Aineiston analyysi}

Koko laadullinen aineisto analysoitiin aineistolähtöisen sisällönanalyysin mallin mukaisesti (Miles \& Huberman 1994). Etnografinen painotus tuli kenttätyön aikana tapahtuvasta jatkuvasta materiaalin lukemisesta ja sen pohjalta kysymysten tarkentumisesta. Analyysin ensimmäinen vaihe tapahtui jo kenttätyövaiheessa, jolloin materiaalia luettiin jatkuvasti ja uutta materiaalia vertailtiin aikaisempaan kerättyyn materiaaliin. Tässä vaiheessa tutkimuskysymykset edelleen tarkentuivat konkreettisemmiksi.

Analyysin toisessa vaiheessa materiaalista etsittiin tutkimuskysymyksiin liittyvät ajatuskokonaisuudet ja niistä tehtiin pelkistykset. Kolmannessa vaiheessa näiden pelkistysten pohjalta alkoi muodostua alakäsitteitä, joista koodattiin niistä muodostuvat yläkäsitteet (ks. Hirvonen \& Nikkonen 2003). Analyysi on kuvattu tarkemmin tulosten yhteydessä.

\section{Tutkimuksen eettisyys}

Etelä-Pohjanmaan sairaanhoitopiiri myönsi tutkimusluvan Eeva-hankkeelle lokakuussa 2004. Luvan myöntämisen yhteydessä todettiin, ettei tarvetta eettisen toimikunnan lausunnolle ole. Muistisairailta henkilöiltä ja heidän läheiseltään pyydettiin kirjallinen suostumus. Suostumuksessa tutkimukseen osallistunut henkilö vakuutti osallistuvansa vapaaehtoisesti tutkimukseen ja ymmärtävänsä mahdollisuutensa kieltäytyä tai perua suostumuksensa koska tahansa syytä ilmoittamatta.

Tutkimuksessa noudatettiin hyvän tieteellisen käytännön eettisiä periaatteita ja siinä sovellettiin tietoisen suostumuksen periaatetta, jonka mukaisesti osallistuja tiesi käyttävänsä teknologista apuvälinettä intervention aikana (Etene 2010). Muistisairaan henkilön kohdalla tässä tietoisen suostumuksen periaatteessa on kuitenkin haasteita, koska tähän sairauteen liittyy jopa päivittäistä vaihtelua kognitiossa. Tutkimuksessa varmistettiin tietyin väliajoin teknologian käytön yhteisymmärrys muistisairaan henkilön kanssa. Hänelle selostettiin jokaisella haastattelukerralla tutkimuksen tavoite, pohdittiin sen tuomia etuja ja mahdollisia haittoja hänen arkeensa. Hänelle kerrottiin myös vapaudesta vetäytyä tutkimuksesta halutessaan. Osallistujille informoitiin heitä koskevien tietojen suojaamisesta, niiden käyttötarkoituksesta ja käyttäjistä.

\section{Tulokset}

Tulokset osoittivat, että haastatteluissa tuotiin esille myös sellaisia tarpeita, joihin teknologialla voitaisiin vastata. Toisaalta analyysi osoitti, että erityisesti muistisairaan omat näkemykset tarpeistaan ja arjen haasteista olivat melko erillisiä teknologisesta näkökulmasta. Muistisairas ei hahmottanut teknologian merkitystä interventiotilanteissa niin vahvasti kuin läheinen eikä orientoitunut jo kartoitusvaiheessa samalla tavalla teknologiseen lähestymistapaan.

Tehdyssä sisällönanalyysissä analyysiyksikkönä oli lause tai lauserakenne, joka kuvasi kotona asuvien muistisairaiden ihmisten ja heidän läheistensä kokemuksia teknologiaan liittyvistä tarpeista ja toiveista. Tämän jälkeen ajatuskokonaisuuksista tehtiin pelkistykset. Pelkistyksistä muodostui kaksitoista alakategoriaa ja niistä kolme yläkategoriaa: Itsemääräämisoikeuden sällyminen, sosiaalisten suhteiden säilyminen ja liikkumisen oikeus ja turvallisuus. (Liitetaulukko 1.)

Tarpeiden kirjo oli laaja ja vain osaan niistä voitiin teknologisilla välineillä vastata. Tulokset kuitenkin antoivat hyvän kokonaiskuvan tarpeista ja toiveista, joihin myös teknologian kehittäjien ja ammattihenkilökunnan tulisi jatkossa kiinnittää huomiota.

\section{Itsemääräämisoikeuden säilyminen}

Sisällönanalyysin ensimmäiseksi yläkategoriaksi muodostui tarve mahdollisimman itsenäisen elämän jatkumiseen sairaudesta huoli- 
matta. Alakategorioiksi löytyivät muistin tukeminen, itsenäisen elämän mahdollistaminen ja alentuneen toimintakyvyn kompensointi. Nämä kaikki osa-alueet tukevat muistisairaan ihmisen autonomiaa. He kaipasivat arkeensa erilaisia muistia tukevia ja muistin heikkenemistä kompensoivia keinoja vaikka ei osannutkaan yksilöidä millaista apua se voisi olla:

Muisti on vähän sellaanen, huonoksi menny. En mä taharo enää muistaa kauan nuota asioota. Siihen tarttis jotain. Emmä tierä.

Muistisairaan puheessa toistui muistin heikkenemiseen liittyvä huoli niin pitkään kuin hänellä oli jäljellä sairaudentunnetta. Tämä aihepiiri puhutti muistisairasta osallistujaa monella tavalla ja on keskustelutilanteessa yhdessä läheisen kanssa välillä huolen, välillä kiistan aihe. Läheiset toivat esiin sitä, mitä haasteita muistin ja toimintakyvyn heikkeneminen tuo mukanaan, kun taas muistisairas pohti muistin heikkenemisen problematiikkaa, siitä johtuvaa huonommuuden kokemusta ja sen kompensointikeinoja.

Tähän ongelmaan liittyivät monet päivittäiset toiminnot, jotka vaikeutuivat sairauden edetessä. Näitä olivat lääkkeiden otto, puhelimen ja lieden käyttö sekä rahan käsittely. Näiden aikaisemmin itsestään selvien taitojen heikkeneminen toi mukanaan masennuksen, epäonnistumisen ja merkityksettömyyden tunnetta. $\mathrm{Ne}$ heikensivät muistisairaan osallistujan kokemusta omasta kyvykkyydestään.

Keskusteluissa punoutui yhteen muistin vaikeudet ja vapauden menettämisen tunne. Muistisairaat toivat itsenäisyyden tarvettaan esiin $\mathrm{mm}$. tilanteissa, joissa he halusivat elää kotona mahdollisimman omatoimisesti ja selviytyä päivittäisistä toiminnoistaan. Läheiset eivät niinkään kiinnittäneet tähän huomiota. Tällöin muistisairas koki, ettei tarvitse niin paljon apua kuin läheiset olisivat nähneet tarpeelliseksi. Hän saattoi kokea kotipalvelukäyntejä olevan liikaa ja heidän oman aikansa tällä tavalla kaventuvan. Ulkopuolisen kontrollin lisääntyminen merkitsi monelle osallistujalle itsenäisen arjen hajoamista.

Itsemääräämisen tarve tuli esiin tässä tutkimuksessa myös uuden teknologisen apuvälineen kohdalla. Usein apuvälineen hankkimisen esittäminen aiheutti tunnereaktion, johon sisältyi ajatus siitä, että välineen hankinta kertoo hänen heikenneistä taidoistaan ja kyvystään toimia itsenäisesti. Tämä taas aiheutti sinänsä harmittoman ja tarpeellisen apuvälineen hylkäämiseen. Esimerkkinä tästä tilanne, jossa sairastunut sanoo miehelleen puhuttaessa mahdollisista apuvälineistä:

Ei oo ollu minkäänlaasia ongelmia, Häh, onko ollu ongelmia? Sano nyt." Silja lähtee välillä levottomasti kävelemään (havinnointi)."Taidan lähteä vanhainkotiin, jos sä tänne kaikkia hommaat. Emmä niin huono oo ku luuletta.

\section{Sosiaalisten suhteiden säilyminen}

Sisällönanalyysin toiseksi yläkategoriaksi nousi sosiaalisen verkoston merkitys osallistujien näkökulmasta. Yksinäisyys oli sekä muistisairaan että läheisen yksi eniten esiin tuomia haasteita kodin arjessa. Yksinäisyyden lieventämisen keinoja pohdittiin paljon. Yksin asuvien muistisairaiden kokemuksissa, joita tutkittavista oli yli puolet, yksinäisyys oli erityisesti esillä.

Erityisesti läheiset olivat huolissaan muistisairaiden läheistensä yksinäisyyden kokemuksista. Tämä huoli korostui ymmärrettävästi nimenomaan yksin asuvien ja niiden sairastuneiden kohdalla, joiden omaiset olivat vielä työelämässä. Tämä huoli heijasteli myös läheisten riittämättömyyden kokemuksia, koska he eivät kokeneet voivansa olla kylliksi läheistensä tukena arjessa.

Yksinäisyys liittyi usein myös ulos lähtemiseen, koska muistisairas koki olonsa kotona yksinäiseksi ja yksitoikkoiseksi ja lähti ulos hakemaan seuraa, mutta ei välttämättä kuitenkaan suuntavaiston pettäessä sitä löytänyt esimerkiksi naapureista. Esiin nousi mm. tarve help- 
pokäyttöisiin kommunikointivälineisiin, joilla muistisairas henkilö saisi läheisiinsä yhteyden kodin ulkopuolelle:

Kun ei osaa enää tuota puhelinta, pakkaa muistikulta pettää. Sais olla helepompi.

Sosiaalisten suhteiden supistumiseen liittyi myös kotiin kohdistuvat uhat. Läheiset toivat esiin erityisenä ongelmana kutsumattomat vierailijat, kuten kaupustelijat ja muut kulkijat. Muistisairaat olivat läheisten mielestä erityisen haavoittuvia, koska päästivät yleensä luottavaisesti kaikki tulijat sisään, eivätkä enää ymmärtäneet rahan arvoa samalla tavalla kuin kognitiivisesti terveet.

Useiden muistisairaiden osallistujien kohdalla oli tapahtunut huijausta ja he itsekin oli pitkään muistanut tapauksen ja kokenut siitä häpeää. Heidän pelkonsa kutsumattomista vieraista johti monessa tapauksessa siihen, että muistisairas piti oveaan lukossa eikä avannut ovea tulijoille. He poistivat jopa ovikellon, etteivät joutuisi pelottaviin tilanteisiin, joissa oven takana on vieraita ihmisiä. Tämä aiheutti myös toivottujen vierailujen vähenemistä ja muistisairaan eristäytymistä kotiinsa. Tästä taas oli seurauksena ulkona liikkumisen ja sosiaalisten suhteiden väheneminen.

\section{Mahdollisuus omatoimiseen liikkumiseen}

Sisällönanalyysin kolmanneksi yläkategoriaksi nousi liikkumiseen liittyvät haasteet ja tarpeet. Muistisairaiden henkilöiden puheessa liikunnan haasteissa painottuivat pääasiassa kaatuminen, mutta myös jonkin verran ulos lukkojen taakse jääminen ja varhaisessa sairauden vaiheessa myös huoli eksymisestä. Läheisillä painottui myös kaatuminen ja ulos lukkojen taakse jääminen, mutta toisin kuin muistisairaalla itsellään, erityisesti ei-toivottu uloslähteminen ja eksymisvaara. Muistisairaan huoli omasta eksymisestään oli melko vähäistä, kun taas läheiselle se oli kuormittava asia.
Kaatumisvaaraan liittyy puheessa usein huimaaminen tai liukkaat kelit, jotka tekivät muistisairaat varovaisiksi liikkumisen suhteen. Kaatumiseen liittyviä kokemuksia oli sekä sisätiloista että ulkoa. Yöaikaan tapahtuviin kaatumisiin liittyi myös vaaratilanteita ja avun odottamista useiden tuntien ajan. Näihin tilanteisiin liittyi usein myös ulos lukkojen taakse jääminen, kun vara-avaimen paikka ei enää ollut muistissa.

Tytär: Taas Viljo löytyy eilen aamulla ulkoa pakkasesta. Oli lähteny alusvaatteesillaan ulos. Ovi meni tietysti lukkohon. Onneksi veli löysi.

Muistisairaan ja läheisen yhteisessä keskustelussa he olivat yleensä yhtä mieltä kaatumiseen liittyvästä huolesta ja pelosta. Tämä aihepiiri, joka liittyy fyysisen toimintakyvyn heikkenemiseen, on muistisairaan itsensäkin helposti hyväksyttävissä oleva haaste toisin kuin esimerkiksi eksymiseen liittyvät asiat, joiden kohdalla muistisairaan oma käsitys eroaa usein selkeästi läheisen käsityksestä.

Sairastunut saattoi kokea, ettei enää selviydy vaikkapa luonnossa liikkumisesta, kuten aikaisemmin selvisi ja on sen takia luopunut näistä sinänsä mielekkäistä asioista. Tämä taas lisäsi heidän kokemustaan omasta kyvyttömyydestään. Eräs muistisairas mies sanoi puhuttaessa marjaan menosta:

Hae lapio ja kaiva kuoppa. Ei musta enää oo.

Läheiset toivat myös esiin, että muistisairaan liikkumisen tarve oli lisääntynyt varsinkin varhaisessa sairauden vaiheessa, mutta ettei yksin liikkuminen ollut enää turvallista.

Muistisairas ei kokenut ulos lähtemistään yleensä ongelmana, mikä vielä lisäsi läheisen kuormitusta. Intervention aikana eniten keskusteluja heidän välillään aiheuttivat juuri nämä ulos lähtemiseen ja eksymiseen liittyvät haasteet. Näissä tilanteissa korostui muistisairaan 
oma käsitys siitä, että kaikella hänen liikkumisellaan oli hyvä syy. Varhaisemman vaiheen he kokivat, että eksymisen pelko esti nauttimasta liikkumisesta ulkona.

Sairauden edetessä ajatus eksymisestä väheni sairaudentunnottomuuden lisääntyessä. Samalla lisääntyi myös ristiriidat läheisten kanssa, jotka liittyivät liikkumisen ja samalla itsemääräämisoikeuden rajoittamiseen. Eksymiseen liittyvät asiat olivat herkkiä aiheita muistisairaalle ihmiselle ja tällöin oltiin myös lähellä itsemääräämisoikeuden kysymyksiä, kun asiasta keskusteltiin muistisairaan ihmisen kanssa. Eräs muistisairas nainen sanoi puhuttaessa eksymistapauksesta:

Mä vaan lähärin naapuriin. Paha mieli, että ajateltiin jotta mä eksyyn.

Varhaisemmassa sairauden vaiheessa muistisairaan liikuntakyvyn ollessa vielä hyvä, eksymispelko oli omaisilla suurimmillaan. Muistisairas henkilö saattoi tehdä pitkiäkin lenkkejä päivittäin purkaakseen ahdistustaan tai vain toteuttaakseen liikunnantarvettaan ja saadakseen siitä mielihyvää. Erityisen ongelmallisiksi läheiset kokivat tilanteen muistisairaan ihmisen asuessa yksin syrjäisillä seuduilla. Monissa tapauksissa oli jo tapahtunut eksymisiä. Myös läheisen kanssa asuvien muistisairaiden ihmisen liikkuminen oli turvatonta, silloin kun he halusivat liikkua yksikseen, tai silloin, kun läheisen poistuessa kotoa muistisairas lähti etsimään läheistään.

Sukulainen kertoo: Mirja näkee pimeällä outoja hahmoja pihalla, kuten miehiä tai kuolleet vanhempansa, ja lähtee ajamaan heitä takaa. (Kenttäpäiväkirja.)

Kun läheiset pelkäsivät muistisairaan henkilön suuntavaiston pettämistä ja eksymistä, he joutuvat turvautumaan myös oven lukitsemiseen ulkopuolelta. Tähän ratkaisuun saattoi omaisilla liittyä suurtakin ahdistusta ja he toivat esiin myös sairastuneen negatiivisia reaktioita tilanteeseen. Toisaalta on myös läheisiä, joille muistisairaan lukitseminen sisään esimerkiksi läheisen kauppamatkan ajaksi oli itsestäänselvyys, eivätkä he kyseenalaista sitä mitenkään. Ratkaisua perusteltiin nimenomaan turvallisuussyillä ja arkeen kuuluvana pakkona. Poika kertoo äitinsä tilanteesta:

Voi tänne jättää moneksikin tunniksi, kun pannaan ovet lukkohon ettei pääse ulos. Ei täällä mitään tapahdu. Kiertäähän se joskus kauhiana ikkunoota, että missä väki.

\section{Pohdinta}

Kotona asuvien muistisairaiden ihmisten ja heidän läheistensä kokemukset teknologisen apuvälineen käyttöön liittyvistä tarpeista ja toiveista voitiin luokitella kolmeen pääluokkaan, jotka olivat itsemääräämisoikeuden säilyminen, sosiaalisten suhteiden säilyminen ja liikkumisen oikeus ja turvallisuus. Haasteita olivat yksinäisyyden kokemus, muistin ja toimintakyvyn heikkenemiseen liittyvät ongelmat ja rajoitettu liikkuminen.

Elämälähtöisen suunnittelun ajattelua (Leikas 2009) soveltaen voidaan muistisairaan ihmisen ja hänen läheisensä teknologisen tarveanalyysin pohjalta todeta, ettei pelkkä laitteen käytettävyyden varmistaminen riitä, vaan laitteen tulee olla tukemassa heidän arkipäivän tavoitteiden saavuttamista. Myös Nygård (2008) on tullut tutkimuksessaan samaan tulokseen ja korostaa myös sairastuneen oman motivaation tärkeyttä, joka syntyy hyödyn ja mielihyvän kokemuksesta arjessa.

Tutkimuksessa ilmeni, että muistisairaan henkilön ja läheisen käsitykset muistisairaan kotona asumisen haasteista ja arjen tarpeista eroavat toisistaan. Sairauden alkuvaiheessa ajatukset arjen haasteista olivat usein samankaltaisia muistisairaalla henkilöllä ja hänen läheisellään. Sairauden edetessä ja sairaudentunnottomuuden lisääntyessä erilaiset fyysiset uhat eivät merkinneet muistisairaalle ihmiselle enää niin 
paljon kuin toisaalta kokemus turvassa olosta ja toisaalta mahdollisuudesta määritellä itse omaa arkeaan. Läheisten kokemuksissa taas korostuivat tarve saada tukea nimenomaan muistin heikkenemisen konkreettisiin seurauksiin päivittäisissä toiminnoissa ja kommunikoinnissa. Huoli fyysisestä turvattomuudesta oli läheisillä suurempi, kun taas muistisairaat ihmiset kokivat enemmän psykososiaalista turvattomuutta. Tämä vahvistaa aikaisempia tutkimustuloksia, joissa on havaittu psyykkisen kuormituksen lieventämisen olevan muistisairaalle ihmiselle suurempi tarve kuin omaiselle (MirandaCastillo, Woods \& Orrell 2013).

Nämä tarpeisiin liittyvät eroavuudet tuovat esiin autonomian ja rajoittamisen välisen ristiriidan ja eettiset kysymykset arjen tasolla: Toteutuuko muistisairaan oma tahto ja itsemääräämisoikeus vai meneekö läheisen kokema fyysisen turvallisuuden vaatimus muistisairaan normaalin riskiä sisältävän elämäntavan edelle (vrt. Marshalla 2009)? Muistisairas ihminen halusi muistaa paremmin ja säilyttää näin sisäisen eheytensä ja itsenäisyytensä, jonka avuksi kaipasi tukea. Nämä muistisairaan ihmisen ja omaisen erilaiset tarpeet ja niihin liittyvät toiveet teknologisen apuvälineen hyödyistä, toivat väittelyä ja ristiriitoja sairastuneiden ja omaisten välille.

Tämän tutkimuksen tulokset vahvistavat liikkumiseen liittyvien haasteiden merkitystä kotona asumisen onnistumisessa. Liikkuminen yksin kodin ulkopuolella ja siihen liittyvät riskit näyttivät kuormittavan erityisesti läheisiä. Muistisairaat ihmiset kokivat liikkumisen rutiininomaisena toimintana, joka täyttää tarvetta elää tavanomaista arkea. Liikkuminen oman kodin ulkopuolella ei näyttäytynyt heille kovinkaan ongelmallisena asiana. Ilmeisesti tähän näkemykseen liittyy se, ettei henkilö välttämättä koe olevansa sairas tai osaa arvioida muistisairautensa etenemistä.. Toisaalta on todettu, että muistisairas muistaa tekevänsä paljon enemmän kuin todellisuudessa tekee eikä välttämättähuomaa"kutistuvaa" maailmaansa, vaan elää muistoissaan edelleen entistä kyvy- kästä elämäänsä (Duggan, Blackman, Martyr \& Van Schaik 2008).

Sisään lukitseminen turvallisuussyistä heijastaa Tedren hahmottelemaa paikoillaan pitämisen kulttuuria (Tedre 2006). Tämänkin tutkimuksen osallistujista jotkut olivat omassa kodissaan osan vuorokaudesta lukittujen ovien takana turvallisuussyistä. Kaikki tutkimukseen osallistuvat muistisairaat henkilöt asuivat yhdessä jonkun läheisensä kanssa eikä kukaan asunut täysin yksin. Heidän liikkumistaan ja itsemääräämisoikeuttaan rajoitettiin kuitenkin toistuvasti. Tässä ollaan muistisairauteen liittyvien eettisten ydinkysymysten äärellä: Kuinka varmistaa turvallisuus viemättä kuitenkaan heidän itsemääräämisoikeuttaan ja oikeutta liikkua vapaasti? Onko koti muistisairaalle ihmiselle oikea paikka, jos hänen oikeuttaan liikkua ja toimia vapaasti rajoitetaan (vrt. Jyrkämä 2015)?

Itsemääräämisoikeuden kaventaminen näyttää olevan yhteydessä myös muistisairaan toimintakyvyn säilymiseen ja sosiaaliseen aktiivisuuteen: Kun esimerkiksi itsenäistä liikkumista lähialueella rajoitetaan, vähennetään myös muistisairaan mahdollisuutta säilyttää fyysistä toimintakykyä ja tavata muita ihmisiä mielekkäällä ja luonnollisella tavalla. Tällöin kavennetaan myös muistisairaan kokemusta kyvykkyydestään.

Tässä tutkimuksessa osallistujien kanssa keskusteltiin yhdessä. Voidaan todeta, että muistisairaiden ihmisten oma kokemus tuli usein esiin heikommin, kun mukana keskustelussa on läheinenkin. Usein läheisellä ei ollut kykyä ja voimavaroja lähteä mukaan muistisairaan ihmisen hitaaseen puheentuottamisen rytmiin, vaan hän kiirehti ja puhui päälle. Heidän kiinteä sosiaalinen sidos vaikutti mahdollisesti siihen, miten yhteneväiset muistisairaan henkilön ja läheisen mielipiteet kotona asumisen haasteita ja tarpeista olivat.

Sekä muistisairas että läheinen kokivat yksinäisyyden ja läheisyyden tarpeen yhdeksi suurimmista haasteita kodin arjessa. Sairastuneen korosti yksinäisyyden kokemuksen lisäksi pit- 
kästymisen tunnetta sekä yksinäisyyteen liittyviä turvattomuuden ja pelon kokemuksia. Muistisairailla ihmisillä on todettu olevan enemmän erityisesti sosiaalista yksinäisyyttä ja eristyneisyyttä kuin ei-muistisairailla (Holmen 2000; Wenger 1994). Tarve sosiaalisen elämän säilymisestä tuli esiin sekä läheisillä että muistisairailla ihmisillä.

Tutkimuksen tulosten pohjalta on kysyttävä, miten muistisairaiden ihmisten kohdalla kyetään toteuttamaan hyvinvointia tukevaa kotihoitoa ihmisen läheisyyden ollessa tärkeimpi toiveita ja sen puutteeseen liittyvän yksinäisyyden ollessa suurimpia haasteita muistisairaan kotona asumisessa. Vanhuspalvelulain ja hallituksen kärkihankkeiden pyrkimys siihen, että ikääntyvät asuvat yhä pidempään kotonaan tukipalvelujen turvin, vaativat uusia keinoja varmistaa erityisesti muistisairaiden ihmisten psyykkinen, sosiaalinen ja fyysinen turvallisuus. Samalla tulisi varmistaa heidän perusoikeutensa arvokkaaseen ja mahdollisimman itsenäiseen elämään.

On mietittävä miten pystytään vastaamaan tutkimuksessa esiin nousseisiin tarpeisiin ja haasteisiin, jotka liittyvät avun saantiin ja tukeen tilanteissa, joissa muistisairas ihminen kokee kutsumattomat vieraat uhkana. Entä miten voidaan tukea kotona asuvia muistisairaita ja heidän läheisiään kaatumiseen, eksymiseen ja lukittuihin oviin liittyvissä haasteissa? Olisikin pohdittava miten teknologisia apuvälineitä voitaisiin tehokkaammin käyttää osana muita tukipalveluita parantamaan muistisairaiden henkilöiden hyvinvointia ja turvallisuutta, sekä vahvistamaan kokemusta turvallisuudesta ja itsemääräämisoikeudesta.

Teknologisiin apuvälineisiin liittyvien toiveiden ja tarpeiden tutkiminen on haasteellista, koska vastauksiin väistämättä vaikuttaa osallistujien aikaisempi tieto olemassa olevista teknologisista apuvälineistä. Näin on erityisesti läheisten kohdalla. Muistisairaan ihmi- sen kongnition lasku vähensi heidän kykyään konkretisoida tarve joksikin apuvälineeksi. He eivät juurikaan kyenneet enää abstraktilla tasolla punnitsemaan teknologisten apuvälineiden tuomia mahdollisuuksia. Toisaalta muistisiraiden ihmisten esiin tuomat tarpeet liittyivät vaikkapa lääkkeenoton muistamiseen tai yhteyden saamiseen poissaolevaan läheiseensä. Tämä haasteellisuus saattaa olla yksi syy siihen, että muistisairaiden ihmisten tarpeista teknologisiin apuvälineisiin liittyen on tehty vähän tutkimusta.

\section{Johtopäätökset}

Tämä tutkimus nostaa esiin tarpeen luoda yhdenmukainen prosessi, jossa tehdään laaja käyttäjien arkielämästä lähtevä tarvekartoitus ennen teknologisen apuvälineen valintaa ja käyttöönottoa. Tarvekartoitus antaa tietoa, jonka pohjalta voidaan valita aidosti muistisairasta ihmistä ja hänen läheistään arjessa hyödyttäviä teknologisia apuvälineitä. Teknologisen apuvälineen tulisi vastata muistisairaan ihmisen tarpeisiin eri vaiheissa sairautta ja vahvistaa hänen kokemustaan omasta kyvykkyydestään ja autonomiastaan. Muussa tapauksessa apuvälineen käytöönottoon ei ole eettisiä perusteita. Teknologisten apuvälineiden suunnittelijoiden ja kehittäjien tulisi myös kiinnittää enemmän huomiota elämälähtöiseen tuotekehitykseen ja pohtia tapoja kehittää laitteista eettisesti ja esteettisesti hyväksyttäviä.

Lisätutkimusta tarvitaan siitä, voidaanko näihin haasteisiin vastata teknologisten apuvälineiden ja sosiaalisen tuen yhdistävillä keinoilla ja mitä nämä keinot voisivat olla.

\section{Yhteydenotto:}

Merja Riikonen, FM, tohtorikoulutettava, Jyväskylän yliopisto, terveystieteiden laitos Sähköposti: merkku.riikonen@gmail.com 


\section{Kiitokset}

Tutkimusta ovat tukeneet Etelä-Pohjanmaan Kulttuurirahasto, Etelä-Pohjanmaan keskussairaala, Miina Sillanpää Säätiö, Alzheimer Säätiö, Alfred Kordelinin säätiön Seinäjoen rahasto, Seinäjoen Yliopistokeskus ja Suomen Kulttuurirahasto. Kiitän myös Etelä-Pohjanmaan terveysteknologian kehittämiskeskusta mahdollisuudesta kerätä aineistoa Eevahankkeen aikana.

\section{Kirjallisuus}

Altus, DE., Mathews, RM., Xaverius, PK., Engelman, KK. \& Nolan. (2000). Evaluating an electronic monitoring system for people who wander. American Journal of Alzheimer Disease and Other Dementias, 15(2), 121-125. https://doi.org/10.1177/153331750001500201

Alzheimer's disease International. (2013). Policy Brief for Heads of Government: The Global Impact of Dementia 2013-2050. World Alzheimer Report. London:Alzheimer's disease International.

Bank, AL., Arguelles, S., Rubert, M., Eisdorfer, C. \& Czaja, SJ. (2006). The value of telephone support groups among ethnically diverse caregivers of persons with dementia. The Gerontologist, 46(1), 134-138.

Baruch, J., Downs, M., Baldwin, C. \& Bruce, E. (2004). A case study in the use of technology to reassure and support a person with dementia. $D e-$ mentia, 3(3), 371-392

Cohen-Mansfield, J., Dakheel-Ali, M., Marx, MS., Thein, K. \& Regier \& NG. (2015). Which unmet needs contribute to behavior problems in persons with advanced dementia? Psychiatry research, 228(1), 59-64. https://doi.org/10.1016/j. psychres.2015.03.043.

Cook, E. J., Randhawa, G., Sharp, C., Ali, N., Guppy, A., Barton, G., Bateman, A. \& Crawford-White, J. (2016). Exploring the factors that influence the decision to adopt and engage with an integrated assistive telehealth and telecare service in Cambridgeshire, UK: a nested qualitative study of patient 'users' and 'non-users'. BMC health services research, 16, 137.

doi: 10.1186/s12913-016-1379-5.
Cummings, J.L., Mega, M., Gray, K, Rosenberg-Thompson, S., Carusi, DA. \& Gornbein, J. (1994). The Neuropsychiatric inventory: Comprehensive assessment of psychopathology in dementia. Neurology, 44(12), 2308-2314.

Duggan, S., Blackman, T., Martyr, A. \& Van Schaik, P. (2008). The impact of early dementia on outdoor life: A "shrinking world". Dementia 7(2), 191-204. https://doi.org/10.1177/1471301208091158

Eloniemi-Sulkava, U. \& Savikko, N. (2011). MielenMuutos - tutkimus- ja kehittämishanke: Tutkimusraportti 3, MielenMuutos muistisairaiden ibmisten hoidossa: käytösoireiden hoidosta muistisairaan ihmisen byvinvoinnin kokonaisvaltaiseen tukemiseen. Helsinki: Vanhustyön keskusliitto.

Eskola, J. \& Suoranta, J. (2000). Johdatus laadulliseen tutkimukseen. Tampere: Vastapaino.

Faucounau, V., Wu, YH., Boulay, M., Maestrutti, M. \& Rigaud, AS. (2009). Caregivers' requirements for in-home robotic agent for supporting community-living elderly subjects with cognitive impairment. Technol Health Care: Official Journal of the European Society for Engineering and Medicine 17(1), 33-40. DOI 10.3233/THC-2009-0537.

Fetterman, DM. (2010). Ethnography. Step by step. Third Edition. Sage Publications, Thousand Oaks, 1-13.

Forsberg, K., Stenberg, L. (2017). Arjen älykkäät välineet. Opas ikääntyneiden kotona asumisen tueksi. Vanhus- ja lähimmäispalvelun liitto ry, Ikäteknologiakeskus.

Hammersley, M. \& Atkinson, P. (1995). Ethnography: principles in practice. Third edition. London: Routledge.

Harris, PB. 2006. The experience of living alone with early stage Alzheimer's disease. What are the person's concerns? Alzheimer's Care Quarterly, 7(2), 84-94.

Helkama, K., Myllyniemi, R. \& Liebkind, K. (2005). Johdatus sosiaalipsykologiaan. Helsinki: Edita.

Hirvonen, E. \& Nikkonen, M. (2003). Tulkitseva etnografia: Sosiaalisen todellisuuden rakentamista, reflektointia ja vakuuttavaa kirjoittamista. Teoksessa Janhonen, S. \& Nikkonen, M. (toim.). Laadullisen tutkimuksen menetelmät hoitotieteessä. Helsinki: WSOY, 265-300.

Holmen, K., Ericsson, K. \& Winblad, B. (2000). Social and emotional loneliness among non-demented and demented elderly people. Archives of Gerontology and Geriatrics, 31(3), 177-192. 
Holstein, MB., Parks, JA. \& Waymack, MH. (2010). Ethics, aging, and society. The critical turn. New York: Springer Publishing Company.

Jyrkämä, J. 2015. Arvokkuuden monet tulkinnat: pohdintoja vanhustenhoidon etiikasta Gerontologia, 29(1), 35-40.

Laki ikääntyneen väestön toimintakyvyn tukemisesta sekä iäkkäiden sosiaali- ja terveyspalveluista 980/2012.

Lawton, MP. (1982). Competence, environmental press, and adaptation of older people. Teoksessa Lawton, MP., Windley, PG. \& Byerts, TO. (toim.), Aging and the environment: Theoretical approaches (s. 33-59). New York: Springer.

Leikas J. (2009). Life-based design-form of life as a foundation for ACT design for older adults. Jyväskylän yliopisto, tietojenkäsittelytieteiden laitos, Studies in computing 105, 147-156.

Leikas, J. \& Saariluoma, P. (2008) “Worth" and mental contents in designing for ageing citizensí form of life. Gerontechnology, 7(3), 305-318.

Marshall, M. (2009). Introduction. The need of people with dementia and their carers and the potential role of design and technology. Teoksessa Topo, P. \& Östlund, B. (toim.) Dementia, design and technology. Time to get involve (s. 3-8.) Assistive technology research series, Vol 24. Amsterdam: IOS Press.

Meiland, FJ., Innes, A., Mountain,G., Robinson, L., van der Roest, H., Garcia-Casal, A., Gove, D., Thyrian, JR., Evans, S., Dröes, RM., Kelly, F., Kurz, A., Casey, D., Szczesniak, D.,Dening, T., Craven, MP., Span, M., Felzmann, H., Tsolaki, M. \& Franco-Martin, M. (2017). Technologies to support community-dwelling persons with dementia: A position paper on issues regarding development, usability, effectiveness and cost-effectiveness, deployment, and ethics. JMIR Rehabilitation and Assistive Technologies, 4(1), e1/1-e1/21.

Meiland, FJ., Hattink, BJ., Overmars-Marx, T., deBoer, ME. Jedlitschka, A., Ebben, PW., Stalpers Croeze II., Flick, S., van der Leeuw, J., Karkowski, IP. \& Dröes, RM. (2014). Participation of end users in the design of assistive technology for people with mild to severe cognitive problems; The European Rosette project. International Psychogeriatrics, 26(5), 769-79. doi: 10.1017/S1041610214000088.

Meiland, FJ., Bouman, AI., Sävenstedt, S., Bentvelzen, S., Davies, RJ., Mulvenna, MD., Nugent,
CD., Moelaert, F., Hettinga, ME., Bengtsson,JE. \& Dröes, RM. (2012). Usability of a new electronic assistive device for community-dwelling persons with mild dementia. Aging E Mental Health,16(5), 584-591.

doi: 10.1080/13607863.2011.651433.

Miles, MB. \& Huberman, AM. (1994). Qualitative data analysis: an expanding sourcebook. Sage: Thousand Oaks.

Miranda-Castillo, C., Woods, B. \& Orrell, M. (2013). The needs of people with dementia living at home from user, caregiver and professional perspectives: a cross-sectional survey. BMC Health services research, 13,1-10 DOI:10.1186/1472-6963-13-43

Miranda-Castillo, C., Woods, B., Galboda, K., Oomman, S., Olojugba, C. \& Orrell, M. (2010). Unmet needs, quality of life and support networks of people with dementia living at home. Health Quality Life Outcomes, 12(8), 132. doi: 10.1186/1477-7525-8-132.

Muistisairaudet. 2017. Käypä hoito -suositus. Suomalaisen Lääkäriseuran Duodecim ja Käypä hoito- johtoryhmän asettama työryhmä. Helsinki: Suomalainen Lääkäriseura Duodecim. päivitys 27.01.2017. Haettu 20.1.2018 osoitteesta: www. kaypahoito.fi.

Mäki, O. \& Topo, P. (2009). Uset needs and requirements of people with dementia. Multimedia application for entertainment. Teoksessa Topo, P. \& Östlund, B. (toim.), Dementia, design an technology: Time to get involve (s. 61-75). Assistive technology research series, Vol 24. Amsterdam: IOS Press.

Nisula, T. (1996). Etnografia ja terveyden tutkiminen - huomioita metodista. Sosiaalilääketieteellinen aikakauslebti 33, 143-151.

Nygård, L. \& Johansson, M. (2001). The experience and management of temporality in five cases of dementia. Scandinavian Journal of Occupation Therapy, 8(2), 85-95. https://doi.org/10.1080/11038120120542.

Nygård, L. (2006). How can we get access to the experiences of people with dementia? Scandinavian Journal of Occupational Therapy, 13(2), 101-112. https://doi.org/10.1080/11038120600723190.

Nygård, L. (2008). The meaning of everyday technology as experienced by people with dementia who live alone. Dementia, 7(4), 481-502. https://doi.org/10.1177/1471301208096631. 
Olsson, A., Engström, M., Lampic, C. \& Skovdahl, K. (2013). A passive positioning alarm used by persons with dementia and their spouses-a qualitative intervention study. BMC Geriatrics, 13(11), 2-9.

https://doi.org/10.1186/1471-2318-13-11.

Petonito, G., Muschert, GW., Carr, DC., Kinney, JM., Robbins, EJ. \& Brown, JS. 2013. Programs to locate missing and critically wandering elders: a critical review and a call for multiphasic evaluation. Gerontologist, 53(1),17-25.

DOI: $10.1093 /$ geront/gns060.

Pot, AM., Willemse, BM. \& Horjus, S. (2012). A pilot study on the use of tracking technology: Feasibility, acceptability, and benefits for people in early stages of dementia and their informal caregivers. Aging \& Mental Health, 16(1), 127-134. doi: 10.1080/13607863.2011.596810.

Taipale, V.(2014). Teoksessa Leikas J. (toim.), Ikäteknologia (s. 4). Helsinki: Vanhustyön keskusliitto.

Tedre, S. (2006). Asunnon vangit - ulos pääseminen sosiaalisena ongelmana. Teoksessa Helne, T. \& Laatu, M. (toim.) Vääryyskirja (s. 161-171). Helsinki: Kansaneläkelaitos.

Sosiaali ja terveysministeriö. (2010). Teknologia ja etiikka sosiaali- ja terveysalan hoidossa ja hoivas$s a$. Valtakunnallinen sosiaali- ja terveysalan eettinen neuvottelukunta. Sosiaali- ja terveysministeriö ETENE. Helsinki: STM.

Sosiaali- ja terveysministeriö (2012). Kansallinen muistiohjelma 2012-2020. Tavoitteena muistiystävällinen Suomi. 2012. Sosiaali- ja terveysmi- nisteriön raportteja ja muistioita 2012:10. Helsinki: STM.

Topo, P. (2015). Tukeeko ympäristö ja teknologian muistisairasta ihmistä? Gerontologia, 4, 219-314.

Topo, P. (2009). Technology studies to meet the needs of people with dementia and their caregivers. A literature review. Journal of Applied Gerontology, 28(1), 5-37. https://doi.org/10.1177/0733464808324019.

Topo, P. (2007). Dementia, teknologia ja etiikka. Gerontologia, 21(3), 221-230.

van der Roest, HG., Wenborn, J., Pastink, C., Droes, R-M. \& Orrell, M. (2017). Assistive technology for memory support in dementia. Cochrane database of systematic reviews 11(6).

doi: 10.1002/14651858.CD009627.

Viramo, P. \& Sulkava, R. (2015). Muistisairauksien epidemiologia. Teoksessa Erkinjuntti, T., Remes, A. \& Soininen, H. (toim.) Muistisairaudet (s. 2339). Helsinki: Duodecim.

Wenger, CG. (1994). Support networks and dementia. International Journal of Geriatric Psychiatry, 9(3), 181-194.

Whall AL. \& Kolanowski AM. (2004). The need-driven dementia-compromised behavior model - a framework for understanding the behavioral symptoms of dementia. Aging Mental Health 8, 106. DOI: $10.1080 / 13607860410001649590$.

Ympäristöministeriö (2017). Älyteknologiaratkaisut ikääntyneiden kotona asumisen tukena. Ympäristöministeriön raportteja 7/2017. 
Liitetaulukko 1. Analyysikaavio

\begin{tabular}{|c|c|c|c|}
\hline Alkuperäinen ajatuskokonaisuus & Pelkistys & Alakategoria & Yläkategoria \\
\hline $\begin{array}{l}\text { Tuo muistikulta on mennyn } \\
\text { niin, etten muista aina asioota. } \\
\text { Kyllä mä haluan niin } \\
\text { omatoimisesti, ettei tarvitte (kodinhoitajien) } \\
\text { aina tulla tänne. } \\
\text { Kun ei enää mitään osaa eikä } \\
\text { mihinkään kelepaa. } \\
\text { Ei tänne pystytä panemahan } \\
\text { sellaasta, josta mä en tykkää, se } \\
\text { saa kyllä lähtiä. Mä oon vielä } \\
\text { sellaanen eukkoo, minä itte. } \\
\text { Mä trossaan ittiäni, etten mitään kompauksia } \\
\text { täällä kotona tee. } \\
\text { Pitäähän täs mies olla vaikkei } \\
\text { mies enää ookkaan. } \\
\text { Niin paljo noloosti pyörittää, } \\
\text { vaikka mä kuinka tarkasti sitä } \\
\text { yritän. Jotta kuinka paljo tuoskin } \\
\text { on pitäny huonota, ettei osaa } \\
\text { pyärittää kunnolla. } \\
\text { Tytär sanoo, että äidin pitää } \\
\text { muistaa, että torvi pitää ensin } \\
\text { nostaa ja sitten vasta painaa. } \\
\text { Äiti: "Sitä mä en havaannu taas. } \\
\text { En mä ny oo hetkehen } \\
\text { soittanukkaan kyllä". (KP). }\end{array}$ & $\begin{array}{l}\text { Tuttu } \\
\text { kotiympäristö } \\
\text { mieluinen } \\
\text { Toive kotona } \\
\text { asumisen } \\
\text { jatkumisesta } \\
\text { Ei muista enää } \\
\text { asioita niin } \\
\text { kuin ennen } \\
\text { Omatoimisuu- } \\
\text { den tärkeys } \\
\text { Epäonnistumi- } \\
\text { sen kokemus } \\
\text { Kotiin ei tuoda } \\
\text { mitään ilman } \\
\text { lupaa }\end{array}$ & $\begin{array}{l}\text { ltsenäisen } \\
\text { elämän } \\
\text { kaventuminen } \\
\text { Oman } \\
\text { kyvykkyyden } \\
\text { epäileminen ja } \\
\text { puolustaminen }\end{array}$ & $\begin{array}{l}\text { Itsemääräämisoikeuden } \\
\text { säilyttäminen }\end{array}$ \\
\hline $\begin{array}{l}\text { Kun ne (vierailijat) panee oven } \\
\text { kiinni, niin sitten se on se itku } \\
\text { apuna, jotta ei sille voi mitään. } \\
\text { Vaikkei täällä mikään päälle } \\
\text { kosta, niin se on se pitkä } \\
\text { yksinäisyys, se on niin kovin } \\
\text { sellaasta synkkää. } \\
\text { "Ne on kyllä kureeta } \\
\text { (kauppiaat). Kyllä mä oon } \\
\text { päättäny, etten anna niille enää } \\
\text { mitään." Tytär: "Mutta kun ei se } \\
\text { muista." Äiti:" Kyllä mä } \\
\text { muistan kuule. Enhän mä ny } \\
\text { niin vielä oo". }\end{array}$ & $\begin{array}{l}\text { Yksin } \\
\text { jääminen } \\
\text { tuntuu synkältä } \\
\text { vaikka } \\
\text { tietääkin että } \\
\text { kotona on } \\
\text { turvallista. } \\
\\
\text { Kaupustelijat } \\
\text { koetaan uhaksi } \\
\text { ja niiden } \\
\text { käynnit } \\
\text { aiheuttavat } \\
\text { väittelyä } \\
\text { perhepiirissä }\end{array}$ & $\begin{array}{l}\text { Yksinäisyys ja } \\
\text { läheisyydentarve } \\
\text { Kutsumattomat } \\
\text { vieraat }\end{array}$ & $\begin{array}{l}\text { Sosiaalisten } \\
\text { suhteiden } \\
\text { säilyttäminen }\end{array}$ \\
\hline
\end{tabular}




\begin{tabular}{|c|c|c|c|}
\hline Alkuperäinen ajatuskokonaisuus & Pelkistys & Alakategoria & Yläkategoria \\
\hline $\begin{array}{l}\text { Se on nauttimista tuo mun } \\
\text { pyörällä kulukeminen, piratän ja } \\
\text { nautin luonnosta. En pirä } \\
\text { kiirusta mihinkään. } \\
\text { No hyvin vähän, kun mua } \\
\text { huimaa niin (liikkuu ulkona), ei } \\
\text { uskalla lähtiä. } \\
\text { Ja kun on eteisen laattialla } \\
\text { maannu niin kauan niin vois olla } \\
\text { jo viimmeenen uni. Se oli liika } \\
\text { kauan tajuttomuutta. } \\
\text { Pahan poukun sain Peltoniemen } \\
\text { reissusta (eksymistapaus), } \\
\text { tärskähdyksen, että nyt en ajele } \\
\text { (polkupyörällä) kuin kylällä. } \\
\text { Vaikka silloon puhuttiin, jotta } \\
\text { minä eksyin, kun menin tuonne } \\
\text { vaan en minä eksyny } \\
\text { silloonkaan. Mä menin aivan } \\
\text { täydellä järjellä, mutta naapurit } \\
\text { pani niin, että minoon eksyny sinne. } \\
\text { Miniä: Nyt sitte Kalle on ollu } \\
\text { vähä pahalla päällä kun on ovet laitettu } \\
\text { lukkoon (ulkoapäin), mutta nyt vaan ollu, } \\
\text { että on joutunu, kun on ollu niin kovat } \\
\text { pakkaset, ei oo oikeen muuta konstia ollu. } \\
\text { myönääny" (lukkojen taakse ulos), } \\
\text { tuntui: "Kyllä se vähä ourolta tuntu, en mä } \\
\text { käsitä kuka hitto sen ..mulla on vara-avaan } \\
\text { ollu aina tuolla... en löytäny sitä. Avain oli aiva } \\
\text { eri paikas mihin mä oli ikänäa sitä pannukkaan. } \\
\text { Kyllä se oli saakeli niin kauhia, kun mun piti } \\
\text { kellarin kautta (mennä sisälle) kun ei avaanta } \\
\text { löytyny.(KP). }\end{array}$ & $\begin{array}{l}\text { Eksyminen } \\
\text { lisää } \\
\text { varovaisuutta } \\
\text { liikkua } \\
\text { Erimielisyydet } \\
\text { eksymisvaarasta } \\
\\
\\
\text { Lukitut ovat } \\
\text { ahdistavat } \\
\text { Hämmennys } \\
\text { lukkojen taakse } \\
\text { jäämisestä }\end{array}$ & $\begin{array}{l}\text { Liikkumisen } \\
\text { nautinto ja } \\
\text { liikkumisen } \\
\text { vähentyminen } \\
\text { Kaatumiset } \\
\\
\text { Eksyminen } \\
\\
\text { Lukitut ovet } \\
\text { eli liikkumisen } \\
\text { estäminen }\end{array}$ & $\begin{array}{l}\text { Liikkumisen } \\
\text { oikeus ja } \\
\text { turvallisuus }\end{array}$ \\
\hline
\end{tabular}

$\mathrm{KP}=$ kenttäpäiväkirja 